\title{
Research on Training Methods of Engineering Literacy for Students Majoring in Automobile Service Engineering
}

\author{
Yufeng Lu* \\ School of Mechanical and Automotive Engineering, \\ QILU University of Technology(Shandong Academy of Science) \\ Jinan, China \\ luyf78@126.com
}

\begin{abstract}
In order to meet the training requirements of automobile service engineering professionals, it is necessary to strengthen the students' engineering literacy. As an important part of the cultivation of students' engineering literacy, the quality of graduation design work needs to be emphasized. Based on the analysis of the connotation of engineering literacy, combined with the characteristics of graduation design of automobile service engineering specialty, this paper proposes ways to improve the engineering ability of graduates. First of all, we should give full play to the role of students and improve the topic selection mode of graduation design. Then, we should strengthen the new mode of school-enterprise joint guidance for graduation design, and pay attention to the cultivation of students' ability in the direction of employment. Finally, the students are classified guidance based on the knowledge levels of themselves.
\end{abstract}

Keywords-Engineering literacy; Graduation design; Schoolenterprise joint; Innovative topic selection mode

\section{INTRODUCTION}

The undergraduates who major in automobile service engineering should meet the needs of modernization and social and technological development. They should be the allround development of moral, intellectual, physical and aesthetic college students. Students of this major need to master the basic theory of modern automobile construction and manufacturing, have basic knowledge of electromechanical engineering and automobile service engineering, basic theory, necessary management and marketing knowledge, and have strong practical and innovative ability of basic automobile inspection, maintenance and service management. Students of this major can be highquality applied talents engaged in automobile testing, marketing; insurance, technical management, technical training and other automobile application technology and service work in automobile-related enterprises and institutions. Automobile service industry involves a wide range of connotations, which determines that the demand for talents in automobile service industry has the characteristics of large number, multi-level and complex [1].

With the rapid development of China's automotive industry, the demand for high-quality talents in the automotive service industry is growing rapidly. The lack of high-quality automotive service personnel has become a bottleneck restricting the development of China's automobile service industry. Therefore, we need to strengthen the training of students majoring in automobile service engineering.

\section{EXISTING PROBLEMS}

At present, automotive service engineering focuses on a series of problems in the automotive aftermarket. Students' employment is mainly oriented to automobile sales, maintenance, insurance and claims settlement, appraisal and evaluation, which is almost the whole automobile industry. This requires that the training of automobile service engineering professionals in Colleges and universities should be oriented to the comprehensive mastery of mechanical, computer, marketing, management and other disciplines, and flexible use of the knowledge of various disciplines of compound talents. However, students can not consider the problem comprehensively, and can't find the most reasonable way of ending [2]. Therefore, the employment unit generally reflects that students' practical ability is not strong.

However, the proportion of practical teaching has been greatly improved in the current teaching of automobile service engineering and many targeted practical projects have been developed. In addition to the original engine disassembly, repair test and so on, the practical teaching of automobile service engineering specialty, such as indemnity, appraisal and evaluation are added.

The main reason for students' weak practical ability is that there are some deficiencies in the cultivation of students' engineering ability. For example, practical teaching can't really be linked to reality. Most practical classes still deal with traditional machines and instruments. They are disconnected from the real demand and development of the automobile market. There are few practical links outside school, and school-enterprise cooperation is not fully in line. Therefore, we need to start from the cultivation of college students' engineering literacy and make use of the existing conditions to improve their practical ability effectively. 


\section{ENGINEERING LITERACY}

Both at home and abroad, great attention has been paid to engineering literacy and its connotation, and it is regarded as one of the important indicators and reference points for engineering education in colleges and universities.

In China's higher engineering education, the term "quality" is traditionally used to express the expectation of students' training goals and abilities. There is no unified understanding of the clear meaning and connotation of engineering literacy. Although there is no clear definition of engineering literacy in the certification of Engineering Education Specialty in China, it is clearly pointed out in the general standards that students' graduation requirements must master the knowledge, skills and literacy to solve complex engineering problems. The complex engineering problems here are highly comprehensive and contain multiple interrelated sub problems.

Therefore, the core content of engineering literacy should include the comprehensive application of technology, economy, law and ethics in order to achieve the goal, which is based on the specific knowledge or technology field, through systematic training and practical training, and in order to meet the specific engineering needs, and in the process follow the general name of engineering methods and laws [3].

Engineering literacy refers to a person's knowledge, working ability and a comprehensive ability to distinguish right from wrong. It should be formed gradually by long-term accumulation of knowledge and its application to work and in distinguishing right from wrong. People with good engineering literacy should have profound knowledge, noble humanistic literacy and moral character, clear thinking ability and thinking consciousness, strong practical operation ability, good innovative thinking ability, profound understanding of Engineering problems, correct social values and sense of social responsibility. Engineering literacy has become an important factor reflecting the comprehensive quality of an engineering college student. Good engineering literacy is a necessary condition for a smooth entry into the work role [4].

Therefore, the cultivation of engineering literacy is not an isolated link, it should be considered from the whole training process. However, according to the characteristics of engineering literacy, we can see that graduation design should be an important part of engineering literacy training. Graduation design with a high credit score is carried out centrally. The total time of graduation design is also the highest in all the courses.

\section{RESOLVENT}

\section{A. Defects in traditional graduation design}

Graduation design, as one of the important components of practical teaching, is not only a comprehensive improvement stage of students' comprehensive quality and engineering literacy, but also one of the main supports of some graduation requirements in engineering education professional certification. However, the quality of undergraduate graduation design in colleges and universities has been declining obviously in recent years. The main reason comes from teachers, students and management mechanism.

(1)The main reasons for the students themselves are: the students' initiative in graduation design is not enough, and their ability to analyze and solve problems is insufficient. College students are accustomed to imitating and copying, and their thinking is not broad enough. Their ability to use knowledge comprehensively is limited. Students devote less time and energy to graduation design.

(2) One of the reasons is that the instructor lacks relevant engineering practice experience. Therefore, the graduation design topics given are not suitable for cultivating students' engineering literacy. There is not enough connection between the topic and the actual design of the graduation project, which lacks the time and novelty. The topic of graduation design is even the topic that the instructor did when he was a student. Because the design results can be obtained through the network and the graduation design of previous students, which causes students to lose interest. This can't achieve any purpose of training students.

Another problem is that in recent years, the proportion of teachers with doctorate degrees in Colleges and universities is increasing. These teachers tend to design graduation design topics from their own perspective. The actual level of undergraduates who are less considered. So the topic of graduation design is too theoretical, too cutting-edge, completely beyond the scope of undergraduate knowledge. A considerable number of graduation design topics come from the scientific research projects and subjects undertaken by the instructor, so that students can closely integrate the new trends of scientific research and production practice. However, many topics often involve specific areas of expertise and deeper theoretical basis. It is not only a huge challenge for undergraduates' knowledge reserve, but also because the topics from scientific research are often theoretical, so that students' graduation design work mainly focuses on theoretical research and computer simulation. Graduation design topics contacted engineering practice and practical application are few, so students can't get complete engineering literacy training [3].

(3) There are also reasons for training units that result in poor quality of graduate design. Graduation design is generally arranged in the last semester of undergraduate training, with a duration of more than 10 weeks. During this period, students are also faced with pressure to find jobs. Some students also face the pressure of reexamination of the postgraduate entrance examination. Therefore, it is difficult for students to settle down to complete their graduation design work.

Of course, there are also employers who sign contracts without training plans to let students blindly go to work ahead of time, and fail to recognize the importance of systematic training for students' practical training. The direct consequence of this is that students are not interested in graduation design. They are perfunctory in doing graduation design, and the effect is not good. However, students can't adapt to their roles as soon as possible after they go to work. Employers are not satisfied with the work of students after 
graduation. Students lack confidence and can't solve practical problems. At the same time, the cost and time of training are increased.

Usually, the assessment and evaluation of undergraduate graduation design takes the evaluation and reply of graduation thesis as the core, ignoring the essential process characteristics and comprehensive characteristics of graduation design. The main concern of the evaluation content is whether the students complete the expected work or not. There is a lack of teachers with engineering background in the defense committee. Therefore, most of the teachers do not care about the engineering problems involved in the defense. There is no direct connection between the degree of integration of the project and engineering practice and the engineering literacy training that the students get. Although the final result of undergraduate graduation design can be expressed by thesis and defense, its quality depends not only on the writing and defense of the thesis itself, but also on the results and quality level of each stage of graduation design[5]. Therefore, in order to improve the role of graduation design in the cultivation of engineering literacy, we must start with the quality control of the whole process. In each link of graduation design, the quality objectives to be achieved and the main factors affecting the quality of the results in the stage are analyzed, and the contents of engineering ability assessment are added.

\section{B. Improvement of Ideas and Implementation Plan}

In view of the shortcomings of traditional graduation design links and the purpose of strengthening the cultivation of students' engineering literacy in graduation design links, combined with the teaching practice of automotive service engineering professionals in our university for many years, this paper puts forward the following suggestions for improvement:

\section{1) Improving the Topic Selection Mode of Graduation Design}

The quality of topic selection is an important factor affecting the quality of graduation design. Careful selection of graduation design topics is the first step to do a good job of graduation design. At present, the topic selection method of our university is that teachers give a certain amount of questions, and then students choose in the system. Because the number of teachers is so small that the number of questions only meets one question per student, it can't give students more choice space, resulting in some students' passive choice of topics, teachers' passive acceptance of students, unable to achieve real mutual selection between teachers and students. However, there is a great difference between students' employment prospects and the selected topics, so that students are not interested in the selected topics, lack of initiative, perfunctory, do not strive for progress, only seek to pass. Aiming at this problem, the following contents are proposed.

a. Strengthen the links between students and teachers. Before choosing a topic, we should hold a teacher-student Symposium and a small academic seminar related to the design topic, so that students can have a good idea of the content and difficulty of the topic, and reduce the blindness in choosing the topic. b. Some students are allowed to draw up their own topics according to their employment orientation, and then the instructor checks the difficulty and workload of the topics, and refines the design topics, and finally forms the topic of graduation design.

\section{2) Exploring the New Mode of School Enterprise Joint} Guidance for Graduation Design

It is an effective way to carry out undergraduate graduation design by letting students go to the employment units to do graduation design, utilizing the funds, venues and technical strength of enterprises, completing the technical issues needed by enterprises, and implementing the joint guidance between schools and enterprises. On the one hand, to enable students to understand and master the whole process of practical engineering design and scientific research and the methods and skills of writing reports and drawings; on the other hand, the practical tasks of the work units are clear, specific, timesensitive, which can stimulate students' enthusiasm and initiative, and enhance their sense of enterprise and responsibility.

Graduation design is the final summary of the practice of the major. When students are about to face employment, in the choice of graduation design topics, focusing on the current forefront of the automotive service industry, it not only conforms to the development of society, but also realizes the combination of graduation design and employment. Therefore, the enthusiasm of students in graduation design is improved.

With interest, students can actively devote themselves to graduation design. Through this process of graduation design, their comprehensive ability has been trained. In the process of graduation design, I know the future work content and enhance the confidence of employment. By understanding the nature and content of the work in advance, they can adapt to the environment quickly and learn to be useful in future jobs. This improves the effect of graduation design.

In terms of automotive service engineering, this is a highly practical profession. Efforts to improve students' engineering literacy are not only the needs of current professional development, but also the needs of social and economic development. The development of China's automotive industry needs high-end talents, senior technicians and a large number of engineers. This requires us to focus on how to cultivate talents who really meet the needs of society, so that the major of Automotive Service Engineering in Colleges and universities can really deliver excellent high-end talents for the society. Thus leading our automobile industry to move towards faster and stronger development ranks.

\section{3) Teaching Students in Accordance With Their Aptitude}

Because of the differences of students themselves, it is impossible for all students to have the same abilities, and there must be good in the middle. In order to solve this problem, it is necessary to provide guidance for graduation design, such as for excellent students, mainly giving guidance on methods and providing relevant information. Of course, the difficulty of these materials is slightly higher than the requirements of their graduation thesis, which requires him to study and assimilate carefully[6]. 


\section{4) Reform Examination and Evaluation Methods}

Differentiated mechanism of graduation design examination and evaluation was introduced. Different evaluation criteria are set up for different topics, and different evaluation rules are given. The students were divided into groups according to the difficulty and types of questions. For theoretical subjects, teachers with doctoral degrees are chosen as respondents, focusing on the depth and rationality of the theory. For engineering practice and product development courses, teachers with engineering experience and practical product development experience are organized to form a defense group. It focuses on students' performance related to engineering literacy cultivation in the process of graduation design. Less attention is paid to whether students publish papers or patents. The final result is biased towards students with strong engineering application [3].

\section{CONCLUSIONS}

On the basis of the training requirements of automobile service engineering specialty and combining with the requirements of the society for the quality of graduates, this paper puts forward the methods to improve the graduation design link and enhance the engineering ability of graduates of this specialty. The number of graduation projects, especially the number of engineering topics was increased so that students can have more choices. Enough subjects were put out to ensure that everyone has the right topic to improve students' enthusiasm for graduation design. The role of enterprises was strengthen in graduation design. It not only enables enterprises to provide practical topics, but also allows enterprises to make recommendations in the process of evaluation.

\section{ACKNOWLEDGMENT}

The results of this study are funded by Postgraduate Education Innovation Program of QILU University and Teaching Research Project of QILU University of Technology(Research on co construction of enterprises and schools to help local universities develop MOOC) and Research project of undergraduate teaching reform in Shandong(K2016M028).

\section{REFERENCES}

[1] Lu Yufeng, "A survey research of college students' learning engagement," Advances in Social Science Education and Humanities Research, vol. 157, pp. 358-361, 2017.

[2] Wu Xuan, "Reflection on the cultivation of professional quality of students majoring in automobile service engineering," Comparative Study of Cultural Innovation, pp.98-99, 2018. (In Chinese)

[3] CHENG Jian-ping, ZHAO Haitao, CHENG Chong-hu, SHEN jianhua "Reform of graduate project mode oriented engineering accomplishment cultivation," .Journal of EEE, vol.39, pp. 127-130,2017. (In Chinese)

[4] SHI Jian,GUO Cuifang, "Engineering literacy training model for applied engineering students," Journnal Of NingBo University of Technology, vol. 28, pp.98-102, 2016. (In Chinese)

[5] GAO Qi, LI Wei-xing, LIAO Xiao-zhong, "The study on whole-proces evaluation system for graduation design of engineering undergraduates,' Research And Exploation In Laboratory, vol.32, pp.393-397,2013. (In Chinese)

[6] Yufeng LU, "Hidden the Moral Education in Teaching of "Automobile Application Engineering"', Advances in Social Science Education and Humanities Research, vol.44, pp.582-585, 2016. 